Curr HIV/AIDS Rep. 2011 September ; 8(3): 133-141. doi:10.1007/s11904-011-0082-8.

\title{
Vitamin D in HIV-Infected Patients
}

\author{
Lake JE, M.D.* \\ UCLA Center for AIDS Research and Education David Geffen School of Medicine at UCLA 9911 \\ W. Pico Blvd., Suite 980 Los Angeles, CA 90035
}

Adams JS, M.D.

UCLA-Orthopaedic Hospital Research Center David Geffen School of Medicine at UCLA 615

Charles E. Young Dr. South, Rm. 410E Los Angeles, CA 90095-7358 P: 310-267-5585 F:

310-825-5409 jsadams@mednet.ucla.edu

\begin{abstract}
Observational studies have noted very high rates of low 25(OH)D (vitamin D) levels in both the general and HIV-infected populations. In HIV-infected patients, low 25(OH)D levels are likely a combination of both traditional risk factors and HIV- and antiretroviral therapy-specific contributors. Because of this unique risk profile, HIV-infected persons may be at greater risk for low 25(OH)D levels and frank deficiency and/or may respond to standard repletion regimens differently than HIV-uninfected patients. Currently, the optimal repletion and maintenance dosing regimens for HIV-infected patients remain unknown, as do potential benefits of supplementation that may be unique to the HIV-infected population. This paper reviews data published on HIV infection and vitamin D health in adults over the last year.
\end{abstract}

\section{Keywords}

vitamin D; 25(OH)D; 1,25(OH $)_{2} \mathrm{D}$; HIV; ART; efavirenz; tenofovir

\section{Introduction}

In recent years, startling rates of low serum levels of the major circulating metabolite of vitamin D (25-hydroxyvitamin D; 25(OH)D $<30 \mathrm{ng} / \mathrm{ml}$ or $75 \mathrm{nmol} / \mathrm{L}$ ) have been documented in the general population. Data from the U.S. National Health and Nutrition Examination Survey (NHANES) suggests $>75 \%$ of persons living in the U.S. have suboptimal circulating levels of vitamin D (1). This degree of vitamin D insufficiency has been associated with cardiovascular disease (CVD), insulin resistance, osteoporosis, and allcause mortality (2-6). As a result, routine screening for for low 25(OH)D levels and supplementation of insufficient patients has become increasingly common. The safety of vitamin $\mathrm{D}$ supplementation at a wide range of doses has been demonstrated for most persons $(7,8)$, and the Institute of Medicine has endorsed the safety of daily oral doses of vitamin D up to 4000 international units (IU) (9).

Observational studies have also noted very high rates of low 25(OH)D levels in HIVinfected patients $(10,11)$, a finding that is likely a combination of both traditional risk factors and HIV- and antiretroviral therapy (ART)-specific contributors. Because of their unique risk profile, HIV-infected persons may be at greater risk for low 25(OH)D levels and frank vitamin D deficiency and/or may respond to standard repletion regimens differently

*Corresponding author P: 310-557-9679 F: 310-557-1899 jlake@ mednet.ucla.edu. 
than HIV-uninfected patients. Due to a lack of prospective, randomized controlled trials (RCTs), the optimal repletion and maintenance dosing regimens for HIV-infected patients remain unknown, as do potential benefits of supplementation that may be unique to the HIVinfected population. This review focuses on data published on HIV infection and vitamin D health in adults over the last year, as well as recent guidelines for vitamin D supplementation in the general population.

\section{Background \\ Vitamin D Physiology}

Detailed descriptions of vitamin D physiology and metabolism have been published elsewhere $(4,12)$. Vitamin D3 (cholecalciferol) is photosynthesized in the skin upon exposure to ultraviolet B (UVB) radiation. Vitamin D2 (ergocalciferol) can be ingested via foods or supplements $(4,12)$. Both forms of vitamin $\mathrm{D}$ are converted in the liver and other tissues to $25(\mathrm{OH}) \mathrm{D}(4,13) .25(\mathrm{OH}) \mathrm{D}$ is further metabolized to its active form, 1,25dihydroxyvitamin $\mathrm{D}\left[1,25(\mathrm{OH})_{2} \mathrm{D}\right]$ by the 25 -hydroxyvitamin $\mathrm{D}-1$-a-hydroxylase, or CYP27B1 (14). This hydroxylation occurs primarily in the kidneys, but extra-renal tissues and immune cells are also capable of $1,25(\mathrm{OH})_{2} \mathrm{D}$ production. This is important because extra-renal formation of $1,25(\mathrm{OH})_{2} \mathrm{D}$ is dependent on local extracellular $25(\mathrm{OH}) \mathrm{D}$ concentrations, pro-inflammatory cytokine levels, and immune stimuli rather than the classic endocrine calcium-parathyroid hormone (PTH) regulatory axis $(15,16)$. Finally, the 25hydroxyvitamin D-24-hydroxylase, or CYP24A1, is reponsible for vitamin D catabolism (14). The interaction of vitamin D metabolites with the cytochrome P450 system is critical to the potential contribution of ART to vitamin D deficiency in HIV-infected patients.

\section{Measurement of Vitamin D Stores}

$25(\mathrm{OH}) \mathrm{D}$ is the best measure of total body vitamin D stores. Levels $<30 \mathrm{ng} / \mathrm{mL}(75 \mathrm{nmol} / \mathrm{L})$ are generally considered insufficient, whereas levels $<20 \mathrm{ng} / \mathrm{mL}(50 \mathrm{nmol} / \mathrm{L})$ represent deficiency (17). Although it is the hormonal form of vitamin $\mathrm{D}, 1,25(\mathrm{OH})_{2} \mathrm{D}$ is not used to monitor vitamin D status because: 1) it has a short serum half-life; 2) it is often converted from 25(OH)D outside the general circulation at the tissue level; and 3) circulating levels may be decreased, normal or elevated in patients with low 25(OH)D levels, making serum measurements unreliable $(18,19)$.

\section{Immune Actions of Vitamin D}

$1,25(\mathrm{OH})_{2} \mathrm{D}$ is active in virtually every organ system. In addition to interacting with PTH at the bone and kidney and stimulating intestinal calcium absorption for delivery to target organs, $1,25(\mathrm{OH})_{2} \mathrm{D}$ plays a critical role in the human immune system. Notably, $1,25(\mathrm{OH})_{2} \mathrm{D}$ : suppresses $\mathrm{T}$ cell activation and genes involved in cell proliferation and differentiation $(16,20)$; downregulates the production of pro-inflammatory cytokines such as TNF-a, IFN- $\gamma$, IL-2, and IL-12, shifting the activated T cell response from a Th1- to a Th2-like response $(15,21,22)$; and plays multiple roles in anti-microbial defense and immune regulation, including monocyte chemotaxis and differentiation into macrophages, nitric oxide production by macrophages, and production of cathelicidin and $\beta$ defensin 4 , anti-microbial peptides whose functions include inhibition of viral replication $(10,15,23-$ 31). Because of vitamin D's critical anti-inflammatory and antimicrobial functions, vitamin $\mathrm{D}$ deficiency has been postulated to play a role in the immune reconstitution inflammatory syndrome (IRIS) (32).

Since HIV-infection is a chronic inflammatory state characterized by a Th1-like response, it is possible that the combination of HIV infection and insufficient local production of $1,25(\mathrm{OH})_{2} \mathrm{D}$ could be additive in promoting pro-inflammatory cytokine generation and 
action (with resultant resultant tissue dysfunction). It is also possible that restoration of extracellular 25(OH)D levels to normal could minimize both ongoing inflammation and the complications of HIV and ART associated with chronic inflammation. Lastly, low 25(OH)D levels could play a role in the severity of infections and malignancies commonly seen in HIV-infected patients.

\section{Risk Factors for Low 25(OH)D Levels in HIV-Infected Patients}

Published rates of vitamin D deficiency/insufficiency among HIV-infected persons vary from $12 \%-100 \%$ (33-38). The use of inconsistent definitions for deficiency/insufficiency, as well as variations in the populations studied, contributes to this discrepancy. Overall, rates of low $25(\mathrm{OH}) \mathrm{D}$ levels are high. This is partly due to traditional risk factors for low $25(\mathrm{OH}) \mathrm{D}$ levels such as lack of exposure to UVB radiation, age, and darker skin pigmentation (4). Interestingly, obesity is consistently a risk factor for vitamin D insufficiency in the general population $(4,39,40)$ but not in HIV-infected patients (41-45). Additionally, data from several cohort studies suggest that HIV-infected patients overall have equal or lower-body mass indices (BMIs) than age-matched controls (46-48), highlighting the likelihood of HIV-specific risk factors for low 25(OH)D levels in this population. For example, elevated TNF-a levels in HIV infection may block PTHstimulated conversion of $25(\mathrm{OH}) \mathrm{D}$ to $1,25(\mathrm{OH})_{2} \mathrm{D}$ in the kidney $(49,50)$.

Both vitamin D and many agents used in the treatment of HIV and opportunistic infections are metabolized via the cytochrome P450 system (10), creating the potential for interactions that could alter the effectiveness of standard vitamin D replacement strategies. For example, the protease inhibitor (PI) and non-nucleoside reverse transcriptase inhibitor (NNRTI) classes of antiretroviral agents have been linked to $1,25(\mathrm{OH})_{2} \mathrm{D}$ deficiency by accelerating the hydroxylation of vitamin $\mathrm{D}$ and it metabolites to non-biologically active compounds (51, 52). While PIs may inhibit the 24-hydroxylases (51), efavirenz is thought to increase both the 25-hydroxylation of vitamin D via CYP3A4 induction (53) and 24-hydroxylation of $25(\mathrm{OH}) \mathrm{D}$ and $1,25(\mathrm{OH})_{2} \mathrm{D}$ via CYP24A1-hydroxyalse (54).

To date, the relationship between vitamin D sufficiency and CD4 T cell count remains unclear, although most studies have shown a positive association $(10,11,49,55,56)$. Similarly, in vitro data supporting a direct effect of vitamin D metabolites on HIV-1 replication is conflicting (reviewed in Villamor, 2006).

\section{Recent Developments}

\section{General Prevalence and Risk Factors}

With increased awareness of low 25(OH)D levels as a potential health risk in HIV-infected persons, cross-sectional and observational data has continued to accumulate. In an analysis of baseline data from the Study to Understand the Natural History of HIV and AIDS in the Era of Effective Therapy (SUN), 70.3\% of HIV-infected adults not on vitamin D supplementation had low $25(\mathrm{OH}) \mathrm{D}$ levels $(<30 \mathrm{ng} / \mathrm{mL}$ or $75 \mathrm{nmol} / \mathrm{L})$ compared with $79.1 \%$ of subjects enrolled in the NHANES 2003-2006 surveys. This difference was statistically significant after adjustment for age, race, and sex. In the SUN study, low 25(OH)D levels were significantly associated with traditional risk factors such as non-White race, higher BMI, decreased physical activity, and hypertension, but not age or sex. Findings unique to HIV-infected subjects included a $98 \%$ increased risk with efavirenz exposure and an observed protective effect of ritonavir exposure (44\% risk reduction)(41). The increased rates of low 25(OH)D levels seen in HIV-infected SUN subjects is in contrast to most other published cohort data, where rates equal or exceed that of the general population. For example, in contrast to the prevalence of low 25(OH)D levels reported by NHANES for the general population $(79.1 \%), 100 \%$ of HIV-infected NHANES subjects had low 25(OH)D 
levels. Factors unique to HIV infection in that subset analysis included CD4 count $<200$ cells $/ \mu \mathrm{L}$ in women only (38). Additionally, in the Swiss HIV Cohort study, rates of low $25(\mathrm{OH}) \mathrm{D}$ levels $(<30 \mathrm{ng} / \mathrm{mL}$ or $75 \mathrm{nmol} / \mathrm{L})$ and frank deficiency $(<12 \mathrm{ng} / \mathrm{mL}$ or $30 \mathrm{nmol} / \mathrm{L})$ following peak sun exposure were $>76 \%$ and $14-18 \%$, respectively, exceeding rates seen in the general Swiss population. Risk factors associated with low 25(OH)D levels in that cohort included NNRTI use, non-White race, and intravenous drug use (57).

In cohorts from two U.S. cities (Houston and New York City), similar rates of 25(OH)D $<30 \mathrm{ng} / \mathrm{mL}(75 \mathrm{nmol} / \mathrm{L}$ ) were seen (both 86\%). Only African American race and BMI were associated with $25(\mathrm{OH}) \mathrm{D}<20 \mathrm{ng} / \mathrm{mL}(50 \mathrm{nmol} / \mathrm{L})(58,59)$. In a small study of primarily Black and Hispanic HIV-infected men on ART in New York, $75.8 \%$ of subjects met criteria for low $25(\mathrm{OH})$ D levels $(<30 \mathrm{ng} / \mathrm{mL}$ or $75 \mathrm{nmol} / \mathrm{L})$ or deficiency $(<20 \mathrm{mg} / \mathrm{mL}$ or $50 \mathrm{nmol} / \mathrm{L})$. In this cohort, NNRTI use (vs. PI) correlated with vitamin D deficiency $(\mathrm{p}=0.0017)$, while tobacco use was associated with severe deficiency $(<10 \mathrm{ng} / \mathrm{mL}$ or $25 \mathrm{nmol} / \mathrm{L})$. A similar cross-sectional study of African American and Hispanic post-menopausal women in New York reported $76 \%$ low $25(\mathrm{OH}) \mathrm{D}$ levels $(<30 \mathrm{ng} / \mathrm{mL}$ or $75 \mathrm{nmol} / \mathrm{L})$ and $36 \%$ deficiency $(<20 \mathrm{ng} / \mathrm{mL}$ or $50 \mathrm{nmol} / \mathrm{L})$. Prevalence rates did not vary by HIV status or ART use and were not associated with traditional risk factors other than African American race (60). In a study of HIV-infected patients in London, $91.3 \%$ had $25(\mathrm{OH}) \mathrm{D}<30 \mathrm{ng} / \mathrm{mL}(75 \mathrm{nmol} / \mathrm{L})$. Black ethnicity, winter season, CD4 nadir $<200$ cells $/ \mu \mathrm{L}$ and current ART use were associated with severe vitamin D deficiency $(25(\mathrm{OH}) \mathrm{D}<10 \mathrm{ng} / \mathrm{mL}$ or $25 \mathrm{nmol} / \mathrm{L})(61)$.

\section{HIV-Specific Risk Factors}

Due to the complex interactions of host response, chronic infection and inflammation, and metabolic consequences of ART, HIV-infected persons could be predicted to have unique risk factors for low 25(OH)D levels. For example, both obesity and lower body weight have been associated with vitamin D deficiency in the setting of HIV infection (41-45, 62, 63). In a study by Conesa-Botella et al, body weight $<70 \mathrm{~kg}$ was associated with a 4.7 -fold risk of $25(\mathrm{OH}) \mathrm{D}<20 \mathrm{ng} / \mathrm{mL}(50 \mathrm{nmol} / \mathrm{L})(42)$. Whether low body weight represents severity of chronic illness, is a surrogate for another factor unique to HIV infection or is an association seen in observational studies that lacks a causal relationship remains unknown. Other HIVspecific factors such as current or nadir CD4 count, HIV-1 viral load and stage of disease have also been inconsistently associated with low 25(OH)D levels to date $(37,42,43,45$, $60-63)$.

In a prospective study of pregnant women enrolled in a multivitamin supplementation trial in Tanzania, Mehta et al found associations between low 25(OH)D levels $(<32 \mathrm{ng} / \mathrm{mL}$ or $80 \mathrm{nmol} / \mathrm{L}$ ) and: BMI $<18 \mathrm{~kg} / \mathrm{m}^{2}$ (RR $1.45,95 \%$ CI 1.04-2.01), severe anemia (RR 1.46, 95\% CI 1.09-1.96), progression to World Health Organization stage III or IV disease (RR 1.25, 95\% CI 1.05-1.50), and all-cause mortality (RR 0.58, 95\% CI 0.40-0.84). No association with CD4 T cell count was observed $(43,64)$. This association of $25(\mathrm{OH}) \mathrm{D}$ and all-cause mortality mirrors that seen in the general population (2).

\section{Vitamin D Repletion in HIV-Infected Patients}

The question of whether HIV-infected patients with low 25(OH)D levels can be successfully repleted with oral supplementation and maintain $25(\mathrm{OH}) \mathrm{D}$ levels in the normal range remains unknown. In a small study, only $40 \%$ of 20 men compliant with oral D3 supplementation successfully repleted to a $25(\mathrm{OH}) \mathrm{D}>30 \mathrm{ng} / \mathrm{mL}(75 \mathrm{nmol} / \mathrm{L})$ after a median of 16 weeks follow-up (65). Interpretation of this data is complicated by low rates of compliance, small sample size, and variation in prescribed dosing regimens. Havens and colleagues demonstrated only a $46 \%$ decline in the prevalence of $25(\mathrm{OH}) \mathrm{D}<30 \mathrm{mg} / \mathrm{mL}$ $(75 \mathrm{nmol} / \mathrm{L})$ following administration of 50,000IU weekly for 12 weeks in their cohort of 
HIV-infected subjects 18-24 years of age and on ART (p<0.001 vs. placebo) (66). Lastly, in a RCT of the effects of 4000IU D3 daily vs. placebo, only subjects on non-efavirenzcontaining regimens saw a statistically significant improvement in $25(\mathrm{OH}) \mathrm{D}$ levels after 12 weeks (efavirenz $+3.6 \mathrm{ng} / \mathrm{mL}$ or $9.0 \mathrm{nmol} / \mathrm{L}, \mathrm{p}=0.383$; non-efavirenz $+5.0 \mathrm{ng} / \mathrm{mL}$ or $12.5 \mathrm{nmol} /$ $\mathrm{L}, \mathrm{p}=0.011$ ) (67). Additional RCTs are needed to establish whether or not oral repletion is successful in the setting of HIV infection, as well as optimal dosing regimens.

\section{Association with ART}

Data on the association of low 25(OH)D levels with ART is conflicting but overall suggests an association may be seen with agents such as efavirenz and tenofovir. Other agents may also contribute to low $25(\mathrm{OH}) \mathrm{D}$ levels, but data is lacking. To date, causal relationships between specific agents and vitamin D insuffiency cannot be inferred, as most studies have been retrospective or cross-sectional and were not designed to assess the direct effects of ART on vitamin D status.

Welz and colleagues found only efavirenz use was associated with severe vitamin D deficiency $(25(\mathrm{OH}) \mathrm{D}<10 \mathrm{ng} / \mathrm{mL}$ or $25 \mathrm{nmol} / \mathrm{L})$ in their analysis of subjects on combination ART (OR 2.0, 95\% CI 1.5-2.7, p<0.001). Additionally, efavirenz exposure was associated with an OR for severe vitamin D deficiency of 1.0003 (95\% CI 1.0001-1.0004) per day of exposure $(\mathrm{p}=0.001)$ (61). Brown and McComsey demonstrated a significant decline in 25(OH)D among patients initiating efavirenz- vs. non-efavirenz-based ART $(\mathrm{p}=0.001)$. Similarly, the prevalence of vitamin D deficiency in that cohort (conservatively-defined as $25(\mathrm{OH}) \mathrm{D}<15 \mathrm{ng} / \mathrm{mL}$ or $37.5 \mathrm{nmol} / \mathrm{L}$ ) was $80 \%$ higher for subjects on efavirenz-containing regimens ( $\mathrm{p}=0.007)(68)$. In the SUN Study, $25(\mathrm{OH}) \mathrm{D}<30 \mathrm{ng} / \mathrm{mL}(75 \mathrm{nmol} / \mathrm{L})$ was associated with efavirenz exposure (OR 1.98, 95\% CI 1.18-3.34). A significant protective effect of ritonavir exposure was also observed (OR 0.56, 95\% CI 0.35-0.89) (41).

In the MONET study, subjects well-controlled on PI- or NNRTI-based regimens were randomized to switch to darunavir monotherapy vs. darunavir +2 nucleoside reverse transcriptase inhibitors (NRTIs). In this predominantly white male population, lower $25(\mathrm{OH}) \mathrm{D}$ levels were associated with efavirenz $(\mathrm{p}=0.0062)$ and zidovudine $(\mathrm{p}=0.015)$ use. In a multivariable analysis of predictors of severe vitamin D deficiency $(25(\mathrm{OH}) \mathrm{D}<10 \mathrm{ng} /$ $\mathrm{mL}$ or $25 \mathrm{nmol} / \mathrm{L}$ ) at screening, however, only zidovudine use was statistically significant (zidovudine OR 2.45, $\mathrm{p}=0.01$; efavirenz OR 1.5, $\mathrm{p}=0.27$ ). After 96 weeks on study, neither efavirenz nor zidovudine remained a predictor of vitamin D deficiency $(25(\mathrm{OH}) \mathrm{D}<20 \mathrm{ng} / \mathrm{mL}$ or $50 \mathrm{nmol} / \mathrm{L}$ ), but subjects discontinuing these medications demonstrated larger incremental increases in 25(OH)D levels than those discontinuing other agents [mean 25(OH)D increase for efavirenz and zidovudine $=3.2 \mathrm{ng} / \mathrm{mL}(8 \mathrm{nmol} / \mathrm{L})$ or $27 \%$, 95\% CI $0.8-5.6 \mathrm{ng} / \mathrm{mL}(2-$ $14 \mathrm{nmol} / \mathrm{L}), \mathrm{p}=0.007]$ (69). In the Dat' AIDS Cohort, both efavirenz and zidovudine use were statistically associated with lower $25(\mathrm{OH}) \mathrm{D}$ levels ( $\mathrm{p}<0.0001$ and $\mathrm{p}=0.0008$, respectively). Interestingly, a positive association betweem $25(\mathrm{OH}) \mathrm{D}$ and tenofovir use was reported, an observation not seen in previous cohort studies (62).

It also remains unclear whether NNRTIs exhibit a class effect on 25(OH)D levels. While associations between efavirenz and vitamin $\mathrm{D}$ insufficiency have been demonstrated fairly consistently, an association with other NNRTIs has not clearly been established $(36,42,70)$. Wasserman and colleagues observed $73.7 \%$ prevalent vitamin D deficiency in NNRTI users compared to $29.7 \%$ in PI users (OR for NNRTI 6.62, 95\% CI 1.91-22.89, p=0.0017). While efavirenz was the predominate NNRTI in that cohort, associations of efavirenz and nevirapine with $25(\mathrm{OH}) \mathrm{D}$ were not reported separately (36). In another study of 89 patients initiating ART, efavirenz and nevirapine $(\mathrm{p}=0.001)$, but not tenofovir or PI use, were associated with 25(OH)D <20ng/mL (50nmol/L) (42). Lastly, efavirenz but not TMC278 (rilpivirine) was shown to affect 25(OH)D levels over 48 weeks in subjects initiating ART 
$(25(\mathrm{OH}) \mathrm{D}$ change: efavirenz $-2.5 \mathrm{ng} / \mathrm{mL}$ or $-6.2 \mathrm{nmol} / \mathrm{L}, \mathrm{p}<0.0001$; rilpivirine $0.2 \mathrm{ng} / \mathrm{mL}$ or $0.6 \mathrm{nmol} / \mathrm{L}, \mathrm{p}=0.57$; between group change $\mathrm{p}=0.0002)(71)$.

Investigators from the Swiss HIV Cohort study demonstrated increased rates of 1hydroxylation only in tenofovir users with sufficient $25(\mathrm{OH}) \mathrm{D}$ levels. Although $1,25(\mathrm{OH})_{2} \mathrm{D}$ levels were lower overall in vitamin D deficient patients, an exponential increase in 1hydroxylation occured as $25(\mathrm{OH}) \mathrm{D}$ levels declined (57), highlighting the physiological need to maintain a $1,25(\mathrm{OH})_{2} \mathrm{D}$ threshold for normal tissue functioning. Since 1-hydroxylation of $25(\mathrm{OH}) \mathrm{D}$ is stimlated in response to low serum calcium or phosphate (72), this data may provide further evidence of tenofovir-induced proximal tubule dysfunction and phosphate wasting $(73,74)$.

Childs and colleagues observed a higher percentage of frank hyperparathyroidism (PTH $>87 \mathrm{pg} / \mathrm{mL}$ ) and higher median PTH values among male tenofovir users ( $41 \%$ vs. $0 \%$ in nonusers, $\mathrm{p}=0.018 ; 80 \mathrm{pg} / \mathrm{mL}$ vs. $55 \mathrm{pg} / \mathrm{mL}, \mathrm{p}=0.02) .82 \%$ of subjects had a $25(\mathrm{OH}) \mathrm{D}<30 \mathrm{ng} / \mathrm{mL}$ $(75 \mathrm{nmol} / \mathrm{L})$ irrespecitve of tenofovir use. Among tenofovir users, PTH was higher in subjects with $25(\mathrm{OH}) \mathrm{D}<30 \mathrm{ng} / \mathrm{mL}(75 \mathrm{nmol} / \mathrm{L}, \mathrm{p}=0.045)$. Regression analysis revealed an independent association of PTH with tenofovir use $(\mathrm{p}=0.017)(75)$. Independent associations between PTH, tenofovir use and low 25(OH)D levels have also been demonstrated by Pocaterra and colleagues (76). These observations are not unexpected, given tenofovir's known associations with secondary hyperparathyroidism (77) and loss of bone mineral density (BMD) (78-80). However, other attempts to confirm the association between PTH and tenofovir use have not been fruitful $(81,82)$. Labarga et al demonstrated an association between PTH elevations and tenofovir use only in subjects with suboptimal vitamin D levels $(25(\mathrm{OH}) \mathrm{D} 15-25 \mathrm{ng} / \mathrm{mL}$ or $37-62 \mathrm{nmol} / \mathrm{L})$, suggesting $25(\mathrm{OH}) \mathrm{D}$ status was the driving force for hyperparathyroidism in these subjects (83). Still, published rates of hyperparathyroidism in HIV-infected patients on ART range from $17-40 \%(33,35)$. If vitamin D deficiency compounds the severity of hyperparathyroidism in patients on ART, vitamin D supplementation could be an easy and inexpensive way to minimize bone loss in these patients.

Some data exists correlating low 25(OH)D levels with non-efavirenz-, non-tenofovircontaining regimens, as well as with ART in general. In a study of HIV-infected Indian men, Paul et al demonstrated a 10-fold increase in vitamin D insufficiency among patients on ART regimens not containing efavirenz or tenofovir (84). The Italian ICONA Cohort demonstrated an association of hypovitaminosis D with duration of ART (OR 1.33 per year, 95\% CI 1.1-1.5, $\mathrm{p}=0.0001$ ) but not individual agents in their large, retrospective analysis of patients initiating ART (85). Lastly, other studies have failed to find any association between ART and low 25(OH)D levels $(37,60,86)$.

\section{Immunologic}

Campbell and Spector demonstrated inhibition of HIV-1 viral replication in human macrophages incubated with $1,25(\mathrm{OH})_{2} \mathrm{D}_{3}$, a process that was partially mediated via autophagy (87). Similar benefits were seen for cells infected with Mycobacterium tuberculosis (Mtb) and co-infected with HIV-1 and Mtb (88). These findings provide further support for the role of vitamin $\mathrm{D}$ as a modulator of human antiviral and antibacterial responses.

\section{Metabolic}

In a cross-sectional study of 1811 HIV-infected patients from Modena, Italy, Szep and colleagues demonstrated an independent association of vitamin D deficiency $(25(\mathrm{OH}) \mathrm{D}$ $<20 \mathrm{ng} / \mathrm{mL}$ or $50 \mathrm{nmol} / \mathrm{L}$ ) with type 2 diabetes after controlling for other factors (OR 1.85, 
95\% CI 1.03-3.32, $\mathrm{p}=0.038$ ) (89). In a retrospective subset analysis of non-diabetic Modena cohort participants $(\mathrm{n}=1574), 30,000 \mathrm{IU}$ of D3 weekly was associated with an $83 \%$ decline in diabetes incidence (HR 0.17, 95\% CI 0.04-0.72) (90). These findings support those of previous studies $(5,6,91)$, and are not surprising given the known role of vitamin D in promoting insulin secretion and insulin-mediated glucose transport (92-95).

Rates of osteopenia and osteoporosis are estimated to be $52 \%$ and $15 \%$, respectively, in HIV-infected patients both on and off ART (96). Welz and colleagues demonstrated an additive effect of efavirenz and tenofovir on alkaline phosphatase, a marker of bone turnover, in the setting of severe vitamin D deficiency (61). In the Women's Interagency Health Study study, loss of femoral neck BMD in premenopausal, HIV-infected women was associated with vitamin D deficiency $(25(\mathrm{OH}) \mathrm{D}<20 \mathrm{ng} / \mathrm{mL}$ or $50 \mathrm{nmol} / \mathrm{L}, \mathrm{p}=0.01)$ but not ART. Specifically, there was no association between efavirenz use or cumulative tenofovir exposure and bone loss (97). In a cohort of HIV-infected Israeli women, women of Ethiopian descent had significantly: higher rates of severe vitamin D deficiency $(25(\mathrm{OH}) \mathrm{D}$ $<10 \mathrm{ng} / \mathrm{mL}$ or $25 \mathrm{nmol} / \mathrm{L}, \mathrm{p}=0.001)$, higher PTH levels $(\mathrm{p}<0.001)$, and lower BMD $(\mathrm{p}=0.001$ at lumbar spine) vs. Caucasian women (98). Other descriptive studies have not demonstrated an association between BMD and low 25(OH)D levels (86). While decreased BMD in the setting of HIV infection is likely multi-factorial, normalization of vitamin D levels in these patients could prevent the additional contribution of low 25(OH)D levels to metabolic bone disease.

Important data linking low 25(OH)D levels to atherosclerotic disease in HIV-infected patients has come to light this year. Choi et al demonstrated a graded, inverse, independent relationship between $25(\mathrm{OH}) \mathrm{D}$ levels and carotid artery intima-media thickness (IMT) in their cross-sectional analysis of patients (99). Similarly, in a study of HIV-infected subjects on ART, Ross and colleagues reported a 10.6-fold increase in the odds of having common carotid artery IMT above the median value in subjects with $25(\mathrm{OH}) \mathrm{D}<30 \mathrm{ng} / \mathrm{mL}(75 \mathrm{nmol} / \mathrm{L})$ (63). While these findings mirror the cardio-protective effects of vitamin D observed in the general population, future studies are needed to verify the role of vitamin D supplementation in atherosclerotic disease in HIV infection. If this relationship is validated, low $25(\mathrm{OH}) \mathrm{D}$ levels would be an easily modifiable CVD risk factor in HIV-infected patients.

\section{Recent Guidelines}

In 2010, both the Institute of Medicine (IOM) and Osteoporosis Canada issued recommendations for vitamin D supplementation. The IOM report stated data supporting vitamin D supplementation on outcomes other than bone health were inconclusive, and suggested that the frequency of vitamin D deficiency in the U.S. and Canada are overestimated. However, an increase in the recommended daily intake of vitamin D from 400IU to 600IU for most adults was made, with a recommended upper supplementation limit of 4000IU per day (9). Given the unique risk for low 25(OH)D levels contributed by HIV infection and ART, it is unreasonable to assume that these guidelines are adequate for HIV-infected patients.

The Osteoporosis Canada guidelines promote more liberal vitamin D supplementation for patients at risk for insufficiency. Their guidelines divide patients into 3 categories: low risk patients that should receive $400-1000 \mathrm{IU}$ daily without $25(\mathrm{OH}) \mathrm{D}$ monitoring, moderate risk patients that should receive 800-2000IU daily without monitoring, and high-risk subjects that should receive enough vitamin D supplementation to maintain 25(OH)D levels $>30 \mathrm{ng} /$ $\mathrm{mL}(75 \mathrm{mmol} / \mathrm{L})$. While these practice guidelines also admit data demonstrating benefits beyond bone health is currently insufficient, the panel concluded that the safety, tolerability, and potential benefits of vitamin D supplementation outweigh the risks of long-term insufficiency (100). 
Given the prevalence of low 25(OH)D levels in HIV-infected patients and the potential for added risk of low 25(OH)D due to chronic comorbidities and/or ART, most patients would be considered medium-to-high risk under Canadian guidelines and should receive a minimum of 800IU daily. However, the authors of this article argue that all HIV-infected subjects should be screened for low $25(\mathrm{OH}) \mathrm{D}$ levels, monitored while on supplementation, and given sufficient supplementation to maintain $25(\mathrm{OH}) \mathrm{D}$ levels $>30 \mathrm{ng} / \mathrm{mL}(75 \mathrm{mmol} / \mathrm{L})$. This recommendation seems reasonable given the high rates of osteoporosis and osteopenia in HIV-infected persons (96), the low risk of supplementation, and the potential for benefits beyond bone health in this population. The controversy over supplementation and the lack of consensus guidelines specific to HIV infection underlie the need for RCTs to critically assess repletion and maintenance regimens, as well as the potential immunologic and physiologic benefits of vitamin D supplementation in HIV-infected patients.

\section{Limitations}

To date, only associations between vitamin D inusfficiency and HIV infection, ART, and HIV-specific risk factors have been made. This is due in large part to the cross-sectional or observational nature of the studies involved, from which causation cannot be demonstrated. The lack of consistency in defining low 25(OH)D levels and frank deficiency, clinical and laboratory endpoints, and supplementation regimens also complicates data interpretation. Prospective, RCT will help elucidate the true role of vitamin D in the setting of HIV, and will better inform clinical decision-making.

\section{Conclusions and Future Directions}

As in the general population, data on low 25(OH)D levels in the setting of HIV infection are emerging. To date, low 25(OH)D levels have been associated with both traditional and HIVspecific risk factors. Of note, the growing body of evidence supporting an association between low 25(OH)D levels and efavirenz and tenofovir use warrants further attention. Low 25(OH)D levels have also been associated with severity of disease in HIV infection and all-cause mortailty.

Sufficient observational data is available to support RCTs for vitamin D supplementation in HIV-infected patients, and their importance cannot be over-emphazized. Repletion and maintenance regimens, as well as the benefits of supplementation in HIV-infected persons, must be critically evaluated before evidence-based practice guidelines can be made.

\section{References}

1. Adams JS HM. Update in vitamin d. J Clin Endocrinol Metab. 2010; 95(2):471-8. [PubMed: 20133466]

2. Melamed ML ME, Post W, Astor B. 25-hydroxyvitamin D levels and the risk of mortality in the general population. Arch Intern Med. 2008; 168(15):1629-37. [PubMed: 18695076]

3. Ginde AA SR, Schwartz RS, Camargo CA Jr. Prospective study of serum 25-hydroxyvitamin D level, cardiovascular disease mortality, and all-cause mortality in older U.S. adults. J Am Geriatr Soc. 2009; (57):9.

4. Lips P. Vitamin D physiology. Prog Biophys Mol Biol. Sep; 2006 92(1):4-8. [PubMed: 16563471]

5. Forouhi NG, Luan J, Cooper A, Boucher BJ, Wareham NJ. Baseline serum 25-hydroxy vitamin d is predictive of future glycemic status and insulin resistance: the Medical Research Council Ely Prospective Study 1990-2000. Diabetes. Oct; 2008 57(10):2619-25. [PubMed: 18591391]

6. Scragg R, Sowers M, Bell C. Serum 25-hydroxyvitamin D, diabetes, and ethnicity in the Third National Health and Nutrition Examination Survey. Diabetes Care. Dec; 2004 27(12):2813-8. [PubMed: 15562190] 
7. Bischoff-Ferrari HA SA, Dawson-Hughes B, Hathcock J, Giovannucci E, Willett WC. Benefit-risk assessment of vitamin D supplementation. Osteoporos Int. 2009

8. Hiremath GS CD, Baynes M, Ratchford JN, Newsome S, Harrison D, Kerr D, Greenberg BM, Calabresi PA. Vitamin D status and effect of low-dose cholecalciferol and high-dose ergocalciferol supplementation in multiple sclerosis. Mult Scler. 2009; 15(6):735-40. [PubMed: 19383644]

9. Medicine Io. Dietary Reference Intakes for Calcium and Vitamin D. Nov.2010 Brief Report. 2010.

10. Villamor E. A potential role for vitamin D on HIV infection? Nutr Rev. May; 2006 64(5 Pt 1):22633. [PubMed: 16770943]

11. Haug C, Muller F, Aukrust P, Froland SS. Subnormal serum concentration of 1,25-vitamin D in human immunodeficiency virus infection: correlation with degree of immune deficiency and survival. J Infect Dis. Apr; 1994 169(4):889-93. [PubMed: 7907645]

12. Holick MF. Vitamin D: a D-Lightful health perspective. Nutr Rev. Oct; 2008 66(10 Suppl 2):S182-94. [PubMed: 18844847]

13. Beard JA, Bearden A, Striker R. Vitamin D and the anti-viral state. J Clin Virol. Jan 15; 2011 50(3):194-200. [PubMed: 21242105]

14. Prosser DE, Jones G. Enzymes involved in the activation and inactivation of vitamin D. Trends Biochem Sci. Dec; 2004 29(12):664-73. [PubMed: 15544953]

15. Peterlik M, Cross HS. Vitamin D and calcium deficits predispose for multiple chronic diseases. Eur J Clin Invest. May; 2005 35(5):290-304. [PubMed: 15860041]

16. Mathieu C, Gysemans C, Giulietti A, Bouillon R. Vitamin D and diabetes. Diabetologia. Jul; 2005 48(7):1247-57. [PubMed: 15971062]

17. Holick MF. Vitamin D deficiency. N Engl J Med. Jul 19; 2007 357(3):266-81. [PubMed: 17634462]

18. Holick MF. High prevalence of vitamin D inadequacy and implications for health. Mayo Clin Proc. Mar; 2006 81(3):353-73. [PubMed: 16529140]

19. Rosen CJ. Clinical practice. Vitamin D insufficiency. N Engl J Med. Jan 20; 364(3):248-54. [PubMed: 21247315]

20. Nagpal S, Na S, Rathnachalam R. Noncalcemic actions of vitamin D receptor ligands. Endocr Rev. Aug; 2005 26(5):662-87. [PubMed: 15798098]

21. Lemire JM, Archer DC, Beck L, Spiegelberg HL. Immunosuppressive actions of 1,25dihydroxyvitamin D3: preferential inhibition of Th1 functions. J Nutr. Jun; 1995 125(6 Suppl): 1704S-8S. [PubMed: 7782931]

22. Rausch-Fan X, Leutmezer F, Willheim M, Spittler A, Bohle B, Ebner C, et al. Regulation of cytokine production in human peripheral blood mononuclear cells and allergen-specific th cell clones by 1alpha,25-dihydroxyvitamin D3. Int Arch Allergy Immunol. May; 2002 128(1):33-41. [PubMed: 12037399]

23. Girasole G, Wang JM, Pedrazzoni M, Pioli G, Balotta C, Passeri M, et al. Augmentation of monocyte chemotaxis by 1 alpha,25-dihydroxyvitamin D3. Stimulation of defective migration of AIDS patients. J Immunol. Oct 15; 1990 145(8):2459-64. [PubMed: 2212648]

24. Orikasa M, Kawase T, Suzuki A. Induction of macrophagic and granulocytic differentiation of murine bone marrow progenitor cells by 1,25-dihydroxyvitamin D3. Calcif Tissue Int. Sep; 1993 53(3):193-200. [PubMed: 8242472]

25. Schauber J, Dorschner RA, Coda AB, Buchau AS, Liu PT, Kiken D, et al. Injury enhances TLR2 function and antimicrobial peptide expression through a vitamin D-dependent mechanism. J Clin Invest. Mar; 2007 117(3):803-11. [PubMed: 17290304]

26. Liu PT, Stenger S, Li H, Wenzel L, Tan BH, Krutzik SR, et al. Toll-like receptor triggering of a vitamin D-mediated human antimicrobial response. Science. Mar 24; 2006 311(5768):1770-3. [PubMed: 16497887]

27. Adams JS, Ren S, Liu PT, Chun RF, Lagishetty V, Gombart AF, et al. Vitamin d-directed rheostatic regulation of monocyte antibacterial responses. J Immunol. Apr 1; 2009 182(7):4289_ 95. [PubMed: 19299728]

28. Bergman P, Walter-Jallow L, Broliden K, Agerberth B, Soderlund J. The antimicrobial peptide LL-37 inhibits HIV-1 replication. Curr HIV Res. Jul; 2007 5(4):410-5. [PubMed: 17627504] 
29. Steinstraesser L, Tippler B, Mertens J, Lamme E, Homann HH, Lehnhardt M, et al. Inhibition of early steps in the lentiviral replication cycle by cathelicidin host defense peptides. Retrovirology. 2005; 2:2. [PubMed: 15656908]

30. Beard JA, Bearden A, Striker R. Vitamin D and the anti-viral state. J Clin Virol. Jan 15.

31. Hong P, CK.; Modlin, R.; Lee, B.; Krutzik, S. HIV-1 ssRNA Triggers a Vitamin D-dependent Antiviral Pathway in Human Monocytes. 15th Conference on Retroviruses and Opportunistic Infections Boston; Massachusetts. Feb. 20082008

32. Conesa-Botella A, Mathieu C, Colebunders R, Moreno-Reyes R, van Etten E, Lynen L, et al. Is Vitamin D deficiency involved in the immune reconstruction inflammatory syndrome. AIDS Research and Therapy. 2009; 6(4):1-5. Journal. [PubMed: 19193217]

33. Van Den Bout-Van Den Beukel CJ FL, Michels M, Sweep FC, Hermus AR, Bosch ME, Burger DM, Bravenboer B, Koopmans PP, Van Der Ven AJ. Vitamin D deficiency among HIV type 1infected individuals in the Netherlands: effects of antiretroviral therapy. AIDS Research and Human Retroviruses. 2008; 24(11):1375-82. [PubMed: 18928396]

34. Garcia Aparicio AM, Munoz Fernandez S, Gonzalez J, Arribas JR, Pena JM, Vazquez JJ, et al. Abnormalities in the bone mineral metabolism in HIV-infected patients. Clin Rheumatol. Jul; 2006 25(4):537-9. [PubMed: 16208429]

35. Rodriguez M, Daniels B, Gunawardene S, GK R. High Frequency of Vitamin D Deficiency in Ambulatory HIV-Positive Patients. AIDS Research and Human Retroviruses. 2009; 25(1):9-14. Journal. [PubMed: 19108690]

36. Wasserman P, DS R. Highly Prevelent Vitamin D Deficiency and Insufficiency in an Urban cohort of HIV-infected Men Under Care. AIDS Patient Care and STD's. Apr; 2010 24(4):223-7. Journal. 2010. [PubMed: 20377437]

37. Bang UC, Shakar SA, Hitz MF, Jespersen MS, Andersen O, Nielsen SD, et al. Deficiency of 25hydroxyvitamin D in male HIV-positive patients: A descriptive cross-sectional study. Scandinavian Journal of Infectious Disease. 2010; 42:306-10.

38. Ahmed S, ZP.; Ninivaggi, M.; Verley, J.; Yasmin, T.; Khan, I.; Feleke, G.; Valluri, A. Prevalence of vitamin D deficiency in HIV population: an analysis of NHANES. Abstracts from the 18th International AIDS Conference Vienna; Austria. Jul. 2010 Abstract2010

39. Bischof MG, Heinze G, Vierhapper H. Vitamin D status and its relation to age and body mass index. Horm Res. 2006; 66(5):211-5. [PubMed: 16900001]

40. Parikh SJ, Edelman M, Uwaifo GI, Freedman RJ, Semega-Janneh M, Reynolds J, et al. The relationship between obesity and serum 1,25-dihydroxy vitamin D concentrations in healthy adults. J Clin Endocrinol Metab. Mar; 2004 89(3):1196-9. [PubMed: 15001609]

41. Dao CN, Patel P, Overton ET, Rhame F, Pals SL, Johnson C, et al. Low vitamin D among HIVinfected adults: prevalence of and risk factors for low vitamin D Levels in a cohort of HIVinfected adults and comparison to prevalence among adults in the US general population. Clin Infect Dis. Feb; 52(3):396-405. [PubMed: 21217186]

42. Conesa-Botella A, Florence E, Lynen L, Colebunders R, Menten J, R M-R. Decrease of Vitamin D Concentration in Patients with HIV Infection on a Non nucleoside Reverse Transcriptase InhibitorContaining Regimen. AIDS Research and Therapy. 2010; 7(40):1-6. Journal. [PubMed: 20051116]

43. Mehta S, Giovannucci EL, Mugusi FM, Spiegelman D, Aboud S, Hertzmark E, et al. Vitamin D Status of HIV-Infected Women and Its Association with HIV Disease Progression, Anemia, and Mortality. Plos One. 2010; 5(1):1-7. Journal.

44. Borderi M, VF.; Cozzi-Lepri, A.; Di Caro, A.; Shlacht, I.; Cassola, G.; Pellizzer, G.; Vecchiet, J.; Re M, C.; d'Arminio Monforte, A.; Icona Fndn Study Group. Prevalence of Hypovitaminosis D among HIV+ Patients Enrolled in a Large Italian Cohort. 17th Conference on Retroviruses and Opportunistic Infections San Francisco; California. Feb. 2010 Abstract2010

45. Adeyemi OM, AD.; French, A.; Weber, K.; Tien, PC.; Glesby, M.; Golub, E.; Merenstein, D.; Sharma, A.; Villacres, AC.; Cohen, M.; WIHS study group. High rates of vitamin D deficiency among HIV-infected and at-risk women in the United States. Abstracts from the 18th International AIDS Conference Vienna; Austria. 2010 July 21; Abstract2010 
46. Kosmiski LA, Bacchetti P, Kotler DP, Heymsfield SB, Lewis CE, Shlipak MG, et al. Relationship of fat distribution with adipokines in human immunodeficiency virus infection. J Clin Endocrinol Metab. Jan; 2008 93(1):216-24. [PubMed: 17940113]

47. Brown TT, Xu X, John M, Singh J, Kingsley LA, Palella FJ, et al. Fat distribution and longitudinal anthropometric changes in HIV-infected men with and without clinical evidence of lipodystrophy and HIV-uninfected controls: a substudy of the Multicenter AIDS Cohort Study. AIDS Res Ther. 2009; 6:8. [PubMed: 19439092]

48. Boodram B, Plankey MW, Cox C, Tien PC, Cohen MH, Anastos K, et al. Prevalence and correlates of elevated body mass index among HIV-positive and HIV-negative women in the Women's Interagency HIV Study. AIDS Patient Care STDS. Dec; 2009 23(12):1009-16. [PubMed: 19909168]

49. Haug CJ, Aukrust P, Haug E, Morkrid L, Muller F, Froland SS. Severe deficiency of 1,25dihydroxyvitamin D3 in human immunodeficiency virus infection: association with immunological hyperactivity and only minor changes in calcium homeostasis. J Clin Endocrinol Metab. Nov; 1998 83(11):3832-8. [PubMed: 9814454]

50. Hanevold CD, Yamaguchi DT, Jordan SC. Tumor necrosis factor alpha modulates parathyroid hormone action in UMR-106-01 osteoblastic cells. J Bone Miner Res. Oct; 1993 8(10):1191-200. [PubMed: 8256656]

51. Cozzolino M, Vidal M, Arcidiacono MV, Tebas P, Yarasheski KE, Dusso AS. HIV-protease inhibitors impair vitamin D bioactivation to 1,25-dihydroxyvitamin D. AIDS. Mar 7; 2003 17(4): 513-20. [PubMed: 12598771]

52. Ellfolk M, Norlin M, Gyllensten K, Wikvall K. Regulation of human vitamin D(3) 25hydroxylases in dermal fibroblasts and prostate cancer LNCaP cells. Mol Pharmacol. Jun; 2009 75(6):1392-9. [PubMed: 19286836]

53. Hariparsad N, Nallani SC, Sane RS, Buckley DJ, Buckley AR, Desai PB. Induction of CYP3A4 by efavirenz in primary human hepatocytes: comparison with rifampin and phenobarbital. J Clin Pharmacol. Nov; 2004 44(11):1273-81. [PubMed: 15496645]

54. Gyllensten K, Josephson F, Lidman K, Saaf M. Severe vitamin D deficiency diagnosed after introduction of antiretroviral therapy including efavirenz in a patient living at latitude 59 degrees N. AIDS. Sep 11; 2006 20(14):1906-7. [PubMed: 16954738]

55. Teichmann J, Stephan E, Lange U, Discher T, Friese G, Lohmeyer J, et al. Osteopenia in HIVinfected women prior to highly active antiretroviral therapy. J Infect. May; 2003 46(4):221-7. [PubMed: 12799147]

56. de Luis DA, Bachiller P, Aller R, de Luis J, Izaola O, Terroba MC, et al. Relation among micronutrient intakes with CD4 count in HIV infected patients. Nutr Hosp. Nov-Dec;2002 17(6): 285-9. [PubMed: 12514921]

57. Mueller NJ, Fux CA, Ledergerber B, Elzi L, Schmid P, Dang T, et al. High Prevalence of Severe Vitamin D Deficiency in Combined Antiretroviral Therapy-naive and successfully treated Swiss HIV patients. AIDS. May 15.2010 24(8):112701134. Journal. 2010.

58. Crutchley R, GJJ. Risk factors for vitamin D deficiency in HIV-1 infected adults in the SouthCentral United States. Abstracts from the 18th International AIDS Conference Vienna; Austria. 2010 July 21; Abstract 2010

59. Gandhi V, KJ.; Psevdos, G., Jr.; Espinoza, F.; Park, J.; Sharp, V. Evaluation of vitamin D levels in HIV-infected patients at the Center of Comprehensive Care, St Luke's Roosevelt Hospital Center, New York, USA. Abstracts from the 18th International AIDS Conference Vienna; Austria. 2010 July 21; Abstract 2010

60. Stein EM, Yin MT, McMahon DJ, Shu A, Zhang CA, Ferris DC, et al. Vitamin D deficiency in HIV-infected Postmenopausal Hispanic and African-American Women. Osteoporosis International. 2010; 10:1-11. Journal.

61. Welz T, Childs K, Ibrahim F, Poulton M, Taylor CB, Moniz CF, et al. Efavirenz is Associated with Severe Vitamin D Deficiency and Increased Alkaline Phosphatase. AIDS. Jul 31; 2010 24(12): 1923-8. Journal. 2010. [PubMed: 20588161]

62. Allavena C, DC.; Rey, D.; Cuzin, L.; Duvivier, C.; Viget, N.; Guillot, P.; Bernrd, J.; Billaud, E.; Raffi, F.; Dat' AIDS Group. Effects of ARV on vitamin D concentration in HIV-infected patients: 
a large prospective cohort analysis. Abstracts from the 18th Conference on Retroviruses and Opportunistic Infections Boston; MA. 2-11 February 27-March 2, 2011; Abstract

63. Ross A JS, Hileman C, Labbato D, Storer N, Tangpricha V, McComsey G. Vitamin D is linked to carotid intima-media thickness and immune reconstitution in HIV-infected individuals. Antivir Ther. in press.

64. Mehta S, SD.; Magusi, F.; Giovanucci, E.; Msmanga, G.; Fawzi, W. Vitamin D HIV-related complications and HIV disease progression in women in Tanzania. Program and abstracts of the 17th Conference on Retroviruses and Opportuistic Infections; San Francisco, CA. 2010. Abstract

65. Childs K, FS.; Factor, S.; Dieterich, D.; Mullen, M.; Branch, A. First Report of Dose/Response Data of HIV-infected Men Treated with Vitamin D3 Supplement. 17th Conference on Retroviruses and Opportunistic Infections San Francisco; California. Feb. 2010 Abstract2010

66. Havens P, HR.; Stephensen, C.; van Loan, M.; Rutledge, B.; Bethel, J.; Pan, C.; Liu, N.; LujanZilbermann, J.; Mulligan, K.; ATN063 Study Team. Vitamin D3 supplementation decreases PTH in HIV-infected youth being treated with TDF-containing combination ART: a randomized, double-blind, placebo-controlled multicenter trial: Adolescent Trials Network Study 063. Abstracts from the 18th Conference on Retroviruses and Opportunistic Infections Boston; MA. 2011 February 27-March 2; Abstract2011

67. Longenecker C, HC.; Carman, C.; Ross, A.; Tangpricha, V.; Seydafkan, S.; Brown, T.; Labbato, D.; Storer, N.; McComsey, G. Vitamin D supplementation and endothelial function among vitamin D-deficient HIV-infected persons: a randomized placebo-controlled trial. Abstracts from the 18th Conference on Retroviruses and Opportunistic Infections Boston; MA. 2011 February 27-March 2; Abstract2011

68. Brown TT, McComsey GA. Association between initiation of antiretroviral therapy with efavirenz and decreases in 25-hydroxyvitamin D. Antiretroviral Therapy. 2010; 15(3):425-9.

69. Fox, J.; Peters, B.; Prakash, M.; Arribas, J.; Hill, A.; C, M. Improvement in Vitamin D Deficiency Following Antiretroviral Regime Change: Results from the MONET Trial. AIDS Research and Human Retroviruses; September; 2010. p. 1-6.Journal2010

70. Lattuada E, Lanzafame M, Zoppini G, Concia E, S V. No Influence of Nevirapine on Vitamin D Deficiency in HIV-Infected Patients. AIDS Research and Human Retroviruses. 2009; 25(8):84950. Editorial. [PubMed: 19618997]

71. Wohl D, DM.; Orkin, C.; Pilotto, JH.; Sungkanuparph, S.; Yeni, P.; Vanveggel, S.; Deckx, H.; Boven, K. Change in vitamin D levels smaller and risk of severe vitamin D deficiency lower among HIV-1-infected, treatment-naive, adults receiving TMC278 compared with EFV: 48-week results from the phase III ECHO trial. Abstracts from the 18th Conference on Retroviruses and Opportunistic Infections Boston; MA. 2011 February 27-March 2; Abstract2011

72. Portale AA, Halloran BP, Morris RC Jr. Physiologic regulation of the serum concentration of 1,25dihydroxyvitamin D by phosphorus in normal men. J Clin Invest. May; 1989 83(5):1494-9. [PubMed: 2708521]

73. Kinai E, Hanabusa H. Renal tubular toxicity associated with tenofovir assessed using urine-beta 2 microglobulin, percentage of tubular reabsorption of phosphate and alkaline phosphatase levels. AIDS. Nov 18; 2005 19(17):2031-3. [PubMed: 16260911]

74. Labarga P, Barreiro P, Martin-Carbonero L, Rodriguez-Novoa S, Solera C, Medrano J, et al. Kidney tubular abnormalities in the absence of impaired glomerular function in HIV patients treated with tenofovir. AIDS. Mar 27; 2009 23(6):689-96. [PubMed: 19262355]

75. Childs KE, Fishman SL, Constable C, Gutierrez JA, Wyatt CM, Dieterich DT, et al. Short Communication: Inadequate Vitamin D Exacerbates Parathyroid Hormone Elevations in Tenofovir Users. AIDS Research and Human Retroviruses. 2010; 26(8):855-9. Journal. [PubMed: 20672993]

76. Pocaterra D, RE.; Carenzi, L.; Schiavini, M.; Meraviglia, P.; Minisci, D.; Campaniello, M.; Gervasoni, C.; Bevilacqua, M.; Rizzardini, G.; Bonfanti, P. Prevalence of hypovitaminosis D and factors associated in a sample of HIV patients. Abstracts from the 18th International AIDS Conference Vienna; Austria. 2010 July 21; 2010

77. Gilead. Viread (tenofovir disoproxil fumarate) package insert. 2010 
78. Gallant JE, Staszewski S, Pozniak AL, DeJesus E, Suleiman JM, Miller MD, et al. Efficacy and safety of tenofovir DF vs stavudine in combination therapy in antiretroviral-naive patients: a 3year randomized trial. JAMA. Jul 14; 2004 292(2):191-201. [PubMed: 15249568]

79. Jacobson DL, Spiegelman D, Knox TK, Wilson IB. Evolution and predictors of change in total bone mineral density over time in HIV-infected men and women in the nutrition for healthy living study. J Acquir Immune Defic Syndr. Nov 1; 2008 49(3):298-308. [PubMed: 18845956]

80. Fux C, HB.; Opravil, M.; Cavassini, M.; Calmy, A.; Gurtner-delaFuente, V.; Schmid, P.; Stoeckle, M.; Flepp, M.; Furrer, H.; Swiss HIV Cohort Study. Bone Turnover, and in Particular Osteoclast Activity, Is Increased in Patients with Confirmed Proximal Renal Tubulopathy within the Swiss HIV Cohort Study. 17th Conference on Retroviruses and Opportunistic Infections San Francisco; California. Feb. 2010 Abstract2010

81. Wirz S, RS.; Christen, A.; Popp, A.; Largiadèr, C.; Mueller, N.; Calmy, A.; Furrer, H.; Fux, C. Renal Phosphate Wasting and Increased Bone Turnover in Tenofovir-treated Patients Are Not Mediated by Low 25(OH) Vitamin D or Hyperparathyroidism. 17th Conference on Retroviruses and Opportunistic Infections San Francisco; California. Feb. 2010 Abstract2010

82. Rosenvinge MM, Gedela K, Copas AJ, Wilkinson A, Sheehy CA, Bano G, et al. Tenofovir-linked hyperparathyroidism is independently associated with the presence of vitamin D deficiency. J Acquir Immune Defic Syndr. Aug 15; 54(5):496-9. [PubMed: 20672448]

83. Labarga P, BP.; Martin-Carbonero, L.; Alvarez, E.; Solera, C.; Pinilla, J.; Vispo, E.; Fernandez, JV.; Gonzalez-Lahoz, J.; Soriano, V. Prevalence and mechanisms of hyperparathyroidism in HIV+ patiens treated with TDF. Abstracts from the 18th Conference on Retroviruses and Opportunistic Infections Boston; MA. 2011 Februrary 27-March 2; Abstract2011

84. Paul TV, Asha HS, Thomas N, Seshadri MS, Rupali P, Abraham OC, et al. Hypovitaminosis D and Bone Mineral Density in HIV Infected Indian Men with or without Antiretroviral Therapy. Endocrine Practice. Jul; 2010 16(4):547-53. Journal. 2010. [PubMed: 20150027]

85. Marco Borderi, FV.; Cozzi-Lepri, A.; Di Caro, A.; Shlacht, I.; Cassola, G.; Pellizzer, G.; Vecchiet, J.; Re, MC.; d'Arminio Monforte, A.; Icona Fndn Study Group. Prevalence of Hypovitaminosis D among HIV+ Patients Enrolled in a Large Italian Cohort. 17th Conference on Retroviruses and Opportunistic Infections San Francisco; California. Feb. 2010 Abstract2010

86. Rachid T, DE.; Meyron, I.; Mandalia, S.; Waters, L.; Bower, M.; Jones, R.; Nelson, M. No association of vitamin D levels with individual antiretroviral agents, duration of HIVinfection, alkaline phosphatase levels nor bone mineral density findings. Abstracts from the 18th International AIDS Conference Vienna; Austria. 2010 July 21; Abstract2010

87. Campbell G, SS. 1,25-dihydroxycholecalciferol Triggers Autophagy in Human Macrophages that Inhibits Productive HIV-1 Infection. 17th Conference on Retroviruses and Opportunistic Infections San Francisco; California. Feb. 2010 Abstract2010

88. Campbell G, SS. Vitamin D3 triggers autophagy in human macrophages that inhibits productive HIV-1/TB co-infection. Abstracts from the 18th Conference on Retroviruses and Opportunistic Infections Boston; MA. 2011 February 27-March 2; Abstract2011

89. Zsofia Szep GG, Shah Samir S. Lo Re Vincent 3rd, Ratcliffe Sarah J. Orlando Gabriella, Carli Federica, Rossi Rosario, Rochira Vincenzo, Tebas Pablo. Vitamin D deficiency is associated with type 2 diabetes mellitus in HIV infection. AIDS. 2011; 25(00)

90. Guaraldi G, ZS.; Orlando, G.; Carli, F.; Ligabue, G.; Stentarelli, C.; Menozzi, M.; Garlassi, E.; Giovanardi, C.; Tebas, P. Vitamin D3 supplementation decreases the risk of diabetes mellitus among patients with HIV infection. Abstracts from the 18th Conference on Retroviruses and Opportunistic Infections Boston; MA. 2011 February 27-March 2; Abstract2011

91. Scragg R, Holdaway I, Singh V, Metcalf P, Baker J, Dryson E. Serum 25-hydroxyvitamin D3 levels decreased in impaired glucose tolerance and diabetes mellitus. Diabetes Res Clin Pract. Mar; 1995 27(3):181-8. [PubMed: 7555599]

92. Maestro B, Campion J, Davila N, Calle C. Stimulation by 1,25-dihydroxyvitamin D3 of insulin receptor expression and insulin responsiveness for glucose transport in U-937 human promonocytic cells. Endocr J. Aug; 2000 47(4):383-91. [PubMed: 11075718]

93. Norman AW, Frankel JB, Heldt AM, Grodsky GM. Vitamin D deficiency inhibits pancreatic secretion of insulin. Science. Aug 15; 1980 209(4458):823-5. [PubMed: 6250216] 
94. Cade C, Norman AW. Vitamin D3 improves impaired glucose tolerance and insulin secretion in the vitamin D-deficient rat in vivo. Endocrinology. Jul; 1986 119(1):84-90. [PubMed: 3013599]

95. Chertow BS, Sivitz WI, Baranetsky NG, Clark SA, Waite A, Deluca HF. Cellular mechanisms of insulin release: the effects of vitamin D deficiency and repletion on rat insulin secretion. Endocrinology. Oct; 1983 113(4):1511-8. [PubMed: 6352248]

96. Brown TT, Qaqish RB. Antiretroviral therapy and the prevalence of osteopenia and osteoporosis: a meta-analytic review. AIDS. Nov 14; 2006 20(17):2165-74. [PubMed: 17086056]

97. Yin MT, Lu D, Cremers S, Tien PC, Cohen MH, Shi Q, et al. Short-term bone loss in HIV-infected premenopausal women. J Acquir Immune Defic Syndr. Feb 1; 53(2):202-8. [PubMed: 19890216]

98. Shahar E, HG.; Kedem, E.; Pollack, S. Low vitamin D levels and bone density changes in young HIV+ Israeli women. Abstracts from the 18th Conference on Retroviruses and Opportunistic Infections Boston; MA. 2011 February 27-March 2; Abstract2011

99. Choi AI, Lo JC, Mulligan K, Schnell A, Kalapus SC, Li Y, et al. Association of Vitamin D Insufficiency with Carotid Intima-Media Thickness in HIV-Infected Persons. Clin Infect Dis. Apr; 52(7):941-4. [PubMed: 21273298]

100. Hanley DA, Cranney A, Jones G, Whiting SJ, Leslie WD, Cole DE, et al. Vitamin D in adult health and disease: a review and guideline statement from Osteoporosis Canada. CMAJ. Sep 7; 182(12):E610-8. [PubMed: 20624868] 